\title{
Single-ventricle reconstruction 2.0: A closer look at our understanding of care for infants undergoing the Norwood procedure
} \author{
Kevin D. Hill, MD, MS ${ }^{\mathrm{d}}$
}

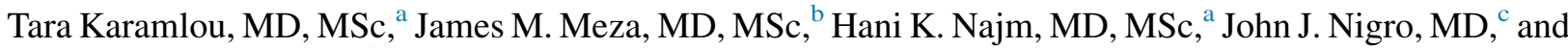

Supplemental material is available online.

Feature Editor's Note-One of the most important congenital heart surgery studies conducted in the past decade was the Single Ventricle Reconstruction (SVR) trial, the results of which were first published in 2010. This randomized, prospective study compared the outcomes of the modified Blalock-Taussig shunt with the Sano right ventricle-topulmonary artery conduit modification for neonates with hypoplastic left heart syndrome undergoing first-stage palliation. It is truly amazing to reflect on the massive number of publications that have now originated from the original SVR trial. One of those is the very important SVR extension study, or SVR II. Newberger and colleagues have just recently reported their 6-year follow-up of the initial SVR cohort. We at the Journal have asked Karamlou and colleagues to provide us with a summary of the very interesting findings from SVR II.

Their careful analysis and summary of SVR II discusses overall survival versus transplant-free survival, addresses practice variation among and within centers, and touches on the concept of regionalization of care to perceived centers of excellence. The analysis also discusses the deployment of alternative initial therapies, such as primary transplantation or hybrid palliation. Finally, the analysis notes the definite benefits of longitudinal surveillance and targeted intervention through interstage home-monitoring programs and how they have improved outcomes. Karamlou and colleagues have beautifully summarized the statistical analysis of SVR II. The frequent use of the word "sobering" in their analysis should cause readers to pay attention.

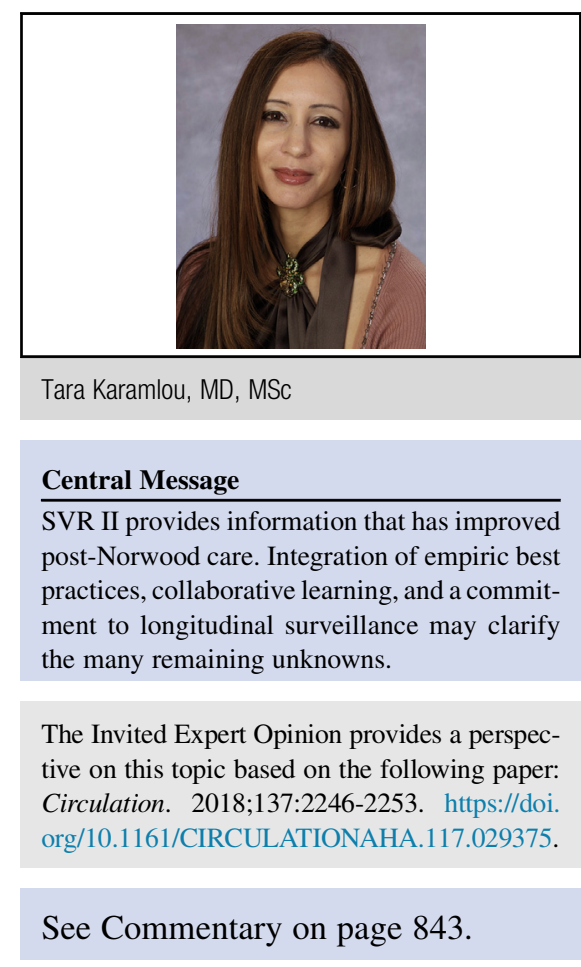

Given the great insights provided by SVR II, one can only wonder what SVR III, SVR IV, and so on will bring!

William Harvey said, "All we know is infinitely less than all that remains unknown," ${ }^{1}$ a statement that, despite the enormous body of literature, encapsulates the current understanding of hypoplastic left heart syndrome (HLHS) The first report from the Single Ventricle Reconstruction II (SVR Extension Study), which was recently published in Circulation by Newburger and colleagues, ${ }^{2}$ details outcomes at 6 years following enrollment in the initial SVR trial. The authors reported on transplant-free survival, catheter interventions, right ventricular function, and adverse clinical events in $331(60 \%)$ of the original study subjects at a mean of $7.1 \pm 1.6$ years following initial Norwood palliation. Three time intervals were investigated, given the hypothesis that treatment effect (ie, shunt type) may vary with palliated stage: before stage II surgery, between stage II surgery and Fontan, and after Fontan. Multivariable Cox proportional-hazard regression and 
Poisson regression analyses were used to identify determinants of time-related transplant-free survival, catheter-based interventions, and adverse clinical events.

Based on their results, the authors provided several interesting, albeit sobering, conclusions. Overall transplant-free survival at 6 years was low and was insensitive to shunt type (64\% for the right ventricle to pulmonary artery shunt [RVPAS] group compared with $59 \%$ for the modified Blalock-Taussig shunt group, $P=.13$ ). Importantly, the magnitude of the treatment effect on the primary endpoint (transplant-free survival) varied across the 3 intervals, validating the presence of nonproportional hazards. The RVPAS group had a lower risk of death or transplant before stage II (hazard ratio [HR], 0.66; $P=.003$ ), with a trend toward increased risk of death during the second interval (HR, $1.36 ; P=.17)$. In the third interval, shunt type was not significantly associated with transplant-free survival, although the HR was lower for the RVPAS group (HR, $0.76 ; P=.52)$. The incidence of catheter interventions was greater among the RVPAS group, predominantly because these patients underwent initial interventions at an earlier age following initial Norwood operation. Finally, serious adverse clinical events were prevalent among all survivors, with $20 \%$ having a neurologic event $(13 \%$ seizure and $7 \%$ stroke), and nearly $16 \%$ having a thrombotic event.

\section{FRAMING OUTCOMES FROM SVR AND SVR II STUDIES IN LIGHT OF CONTEMPORARY RESULTS FOLLOWING THE NORWOOD PROCEDURE}

Given that the mid-term results for infants following Norwood reconstruction in this latest SVR II report are not ideal, can data from other contemporary studies frame or contextualize these? A few points are worth mentioning. First, the study population, which was recruited from Pediatric Heart Network core centers and other selected ancillary sites, will obviously only have outcomes reflective of these particular institutions. Depending on the performance of the SVR centers relative to all centers performing staged palliation, this may lead to a study cohort that might have disproportionately better or worse outcomes. Regardless, the somewhat-sobering results of the SVR II trial must be taken in the context of the wide variation in Norwood procedure in-hospital mortality from the SVR trial (9\%-39\%). ${ }^{3}$ Further, participants in the SVR trial included HLHS and its variants (morphologic right ventricle) undergoing Norwood reconstruction, which also may lead to comparatively better outcomes than isolated HLHS cohorts. However, SVR II results do resonate with recent multicenter reports. ${ }^{4-7}$ The Society of Thoracic Surgeons' Congenital Heart Surgery Database (STS-CHSDB) 2018 annual report documents Norwood operative mortality of $15.8 \%$, which is consistent with the $16 \%$ Norwood hospital mortality rate reported in the SVR trial. ${ }^{4,5}$ The third update from the PHN-sponsored Fontan cross-sectional cohort (Fontan1) reported initial good survival among post-Fontan patients $(90 \%$ at 9.4 years) but steady attrition coupled with decreased exercise performance and functional health status thereafter, ${ }^{6}$ suggesting that patients have important impairments beyond mortality. Similarly, the latest multi-institutional report from the Congenital Heart Surgeons' Society (CHSS) cohort of infants with critical left heart obstruction undergoing Norwood procedure reported an early hazard phase with 6-year overall survival of $70 \%$ for RVPAS and $55 \%$ for modified Blalock-Taussig shunt. ${ }^{7}$ Importantly, the survival curves diverged during the first 1.5 years post-Norwood, with nearly parallel trajectories thereafter, suggesting that the late survival advantage for patients with RVPAS was attributable to the mitigation of interstage death in this group.

Carillo and colleagues ${ }^{8}$ reported contemporary 5-year overall survival for HLHS variants following Norwood procedure at their institution of $58 \%$. Other contemporary single-institution studies have shown better 5-year results. Martin and colleagues ${ }^{9}$ reported $72 \%$ 5-year overall survival for infants with HLHS compared with $77 \%$ 5-year overall survival for infants without HLHS following the Norwood procedure. Karamlou and colleagues ${ }^{10}$ reported a single-institutional series with $90 \%$ overall 5-year survival among infants with isolated HLHS undergoing RVPAS from 2010 to 2016, which reflected a significant era-dependent improvement from the 5 preceding years. Although such single-center studies have, at times, led to optimism that improved outcomes might be attainable, consistently multicenter studies have painted a more sobering picture. As with many complex problems in which there is data variance, the devil is in the details.

\section{OVERALL SURVIVAL VERSUS TRANSPLANT- FREE SURVIVAL: MEASURING SUCCESS IN THE CONTEXT OF LONGER-TERM OUTCOMES}

Clearly, some of the discrepancy in the reported outcomes is due to different reported outcomes. Transplantfree survival, necessarily lower then overall survival, was the metric chosen in the SVR Trial. The rationale for this composite endpoint is articulated in the statement from Ohye and colleagues, ${ }^{11}$ "The fundamental question to answer in a surgical trial in this population, therefore, is whether the child survives to at least 1 year old, and whether the heart requires replacement before then. The primary outcome, death or transplant by 12 months of age, reflects this clinical imperative." Although few would disagree with the utility of this clear, unambiguous endpoint at 1-year post-Norwood, there may be significant limitations to this metric in the longer term. Overall survival is an alternative outcome, which may be more meaningful within the current context of single-ventricle palliation, reflecting the perspective that heart transplant may be an inevitable step in the sequence of single-ventricle palliation. Transplant, 
therefore, should not equate to failure for these patients because of the inherent palliative nature of singleventricle pathways and the fact that appropriate triage to transplant may salvage patients not expected to have long-term Fontan durability. One philosophy, which was proposed by Karamlou and colleagues, ${ }^{10}$ is to aggressively manage correctable hemodynamic lesions, including arch obstruction and tricuspid valve insufficiency, and if ineffective or unlikely to be successful, to transition patients to transplant proactively. The current SVR II data ${ }^{2}$ demonstrate significant ongoing attrition beyond Stage 2 palliation, suggesting that early survival may not necessarily be sustainable or predictable. Similar trends were observed in an analysis from the CHSS, ${ }^{12,13}$ which investigated the optimal timing of Stage 2 palliation among a cohort undergoing Norwood operation for critical left heart obstruction. High-risk patients had markedly increased mortality following stage 2 palliation (28\% compared with $2 \%$ for the low-risk cohort). Moreover, triaging these patients to earlier stage 2 resulted in reduced survival. Data from this large, prospective, multi-institutional series therefore suggested that early referral to transplant would be the preferred strategy to decrease mortality in the longer term.

Other studies have demonstrated that outcomes for transplant following Norwood palliation are generally encouraging, despite waitlist attrition. ${ }^{14-16}$ Quality of life, which has not been assessed directly among survivors in the SVR trial, but is known to decline monotonically among Fontan survivors, ${ }^{17}$ may be rescued with early transplantation. Expanding our current definitions of successful singleventricle palliation to include health-related quality of life and physical functioning may further support the virtues of an overall survival metric that acknowledges the potential advantage of heart transplant. Certainly, optimum timing for deployment of transplantation and defining the physiologic and hemodynamic profile of candidate patients remain unanswered questions but are clearly critical in realizing the full benefit of transplantation and using a scarce resource judiciously. Ensuring that patients and their families understand the commitment inherent in transplantation coupled with the potential for graft failure over time are equally vital, and these messages must be emphasized by all providers. Although very early transplant may have salutary effects regarding graft longevity, transplantation in older children clearly will expose the recipient to a longer at-risk period and may increase the overall prevalence of re-transplantation.

Despite the resource-intensive nature of transplantation from an individual, institutional, and population health perspective, Gajarski and colleagues ${ }^{18}$ synthesized one circumspect perspective in their paper comparing the costs of Fontan palliation with the costs of transplantation, "although the expenditure for heart transplantation far exceeds that for Fontan procedure, Fontan palliation in high-risk patients is ultimately more costly and increases postoperative morbidity. In this subgroup, we recommend heart transplantation as the initial definitive procedure because it may increase long-term survival rates and minimize health care expenditures." We would further submit that the poorly palliated single-ventricle patient requires a similar (if not more intensive) investment in terms of dedicated surveillance, maintenance medications, readmissions, reinterventions, and reoperations to achieve survival. In essence, an equitable comparison of the overall care burden should include transplantation compared with the chronic care pathway experienced by patients with suboptimal single-ventricle physiology. Moreover, achieving equivalent health-related quality of life and functional status among the poorly palliated single-ventricle patient, if possible, may require additional upregulation of care and therefore further favor transplantation. Going forward, it is plausible that adding overall survival as a primary outcome as the SVR cohort matures would provide important information to inform criteria and timing for patient triage to transplantation.

\section{A PERSPECTIVE ON THE LESSONS LEARNED FROM THE SVR TRIAL: SOME ANSWERS AND MORE QUESTIONS}

Beyond being the first prospective randomized controlled trial examining 2 surgical approaches in congenital cardiac surgery (a remarkable accomplishment in its own right), this landmark trial has brought important additional insights to our specialty. Since the initial publication in $2010,{ }^{3}$ there have been 83 published post hoc studies, some of which have come from the SVR public use dataset (Table E1). But what have we learned from this immense body of knowledge, and how can we synthesize the vast amount of information to inform care for infants undergoing the Norwood procedure? Fraser's editorial summarized the position that shunt type may be of relatively lesser importance in the overall outcome of patients and that each surgeon/center should choose shunt type according to what they are most comfortable performing. ${ }^{19}$ It is possible that the impact of surgeon-modifiable has been overemphasized in the context of the entire longitudinal course of a single-ventricle patient - a lifetime of medical care punctuated by discrete surgical events. Clearly, there remain many unanswered questions. Where do we invest future collective resources and direct scientific focus? Are there alternative strategies that can be leveraged to improve outcomes among patients with HLHS?

\section{UNDERSTANDING AND POSSIBLY REDUCING PRACTICE VARIATION AMONG AND WITHIN CENTERS}

Data from the STS-CHSD ${ }^{20}$ would suggest that optimum results following the Norwood procedure are predominantly related to institutional factors rather than surgeon 
factors, and, consistent with this, an important lesson learned from the SVR trial relates to the tremendous variability in practices across centers. Pasquali and colleagues ${ }^{21}$ summarized variability in Norwood hospitalization outcomes and practices; across the 15 SVR trial sites, inhospital mortality ranged from $7 \%$ to $39 \%$, delayed sternal closure from $35 \%$ to $100 \%$, extubation within 72 hours of Norwood from $5 \%$ to $63 \%$, and percentage of patients discharged home on all oral feeds from 3\% to $81 \%$. Hill and colleagues $^{22}$ evaluated rates of arch re-intervention (surgical or transcatheter) for re-coarctation at or before stage II surgery and found center-level re-intervention rates ranging from $0 \%$ to $50 \%$ across the 15 SVR centers with very little consistency in terms of catheter-derived gradients used as interventional thresholds. Oster and colleagues ${ }^{23}$ summarized rates of discharge digoxin use in SVR patients; some centers discharged $0 \%$ of arrhythmia-free patients on digoxin, whereas others discharged 100\%. Importantly, patients discharged on digoxin were found to have an HR for mortality 3.5-fold lower than those not taking digoxin. ${ }^{23}$

The present SVR II update does not include data regarding longitudinal practice patterns. However, there are data from the National Pediatric Cardiology Quality Improvement Collaborative as well as ad-hoc data from the SVR trial that demonstrate persistent variability in the management of post-Norwood infants through Stage II. ${ }^{24,25}$ Furthermore, the National Pediatric Cardiology Quality Improvement Collaborative studies and other publications from national quality collaboratives across adult cardiac and pediatric specialties ${ }^{26-28}$ suggest that variability may lead to suboptimal performance and increased health care cost.

The Northern New England Cardiovascular Study Group developed the initial structural framework for a regional quality collaborative in adult cardiac surgery and delineated the need to precisely assess variation in institutional practice and outcomes, develop empirically based best practices, and then implement guidelines across participants. ${ }^{26,28}$ One of the major obstacles to the development of best practices within congenital heart disease generally (and the Norwood population specifically) is the lack of standardized definitions for prevalent and important complications (such as arch obstruction), which confounds the ability to study these outcomes at centers and establish meaningful performance benchmarks. Devlin and colleagues ${ }^{29}$ recently demonstrated significant institutional variability among 27 centers participating in the CHSS left ventricular outflow tract obstruction cohort with regard to the threshold and approach to arch obstruction following Norwood palliation. Although arch interventions were extremely common among patients $(25 \%)$, and occurred at the vast majority of centers $(\mathrm{N}=19 ; 83 \%)$, preintervention arch gradient ranged from 0 to $64 \mathrm{~mm} \mathrm{Hg}$, suggesting an absence of a consensus threshold. Even within the same institution, there was no correlation between arch intervention frequency and median preintervention gradient. Perhaps more germane to the discussion within the context of the SVR report was the finding that institutional practice was associated with an increased prevalence of arch intervention regardless of arch gradient or other patient factors. ${ }^{29}$

Recognizing that multiple factors, including systemic ventricular function, overall clinical status, and the presence of other hemodynamically significant lesions may all impact the decision to proceed with an intervention, it would seem appropriate to establish a range of acceptable criteria as a start. Work from the Pediatric Cardiac Critical Care Consortium-PHN collaborative learning studies (early extubation) suggest that structured implementation of protocols based on extrapolated study of high-performers is a successful strategy to reduce variation and improve targeted outcomes among participants. ${ }^{30}$ Unfortunately, the sustainability of trial protocols was limited, with $75 \%$ of centers reverting back to pre-trial performance. Clearly, longitudinal and enduring quality improvement must be scalable, systemic, and involve significant commitment of personnel and other resources.

\section{REGIONALIZATION OF CARE TO PERCEIVED CENTERS OF EXCELLENCE}

Regionalization has been considered as another potential avenue to improved congenital heart surgery outcomes, given the inverse relationship between case volume and in-hospital mortality. ${ }^{31,32}$ Further, because of the comparably high mortality and morbidity among neonates undergoing the Norwood procedure, patients with HLHS may be the most likely to benefit from a CHS system that consolidates care at high-volume perceived centers of excellence. ${ }^{20,32}$ Welke and colleagues ${ }^{31}$ recently published data from the United States (15,887 patient discharges from 2012) demonstrating that regionalization of care to the greatest volume quartile of hospitals already occurs in the current CHS system, with $25 \%$ of patients traveling $>100$ miles and $53 \%$ bypassing their nearest CHS hospital. This group also showed that the current CHS system is inherently inefficient, with $66 \%$ of hospitals located within 25 miles of one another-a pattern that was amplified among very low volume hospitals ( $\leq 20$ cases per year). Whether theoretical regionalization of all US centers based on volume thresholds or case complexity will result in important decline in death rates is unclear, but extrapolation from a previous study in California ${ }^{33}$ would support this contention. The potential benefits of a regionalized system have been recognized by several countries. ${ }^{34,35}$ Sweden consolidated pediatric heart surgery from 4 hospitals to 2 , which was coincident with decreased national mortality rate from $9.5 \%$ to $1.9 \%,{ }^{34}$ and the National Health Service of the United Kingdom, in their Safe and Sustainable 
initiative, proposed a restructuring of CHS hospitals to an ideal volume of 500 cases per year with 4 surgeons per center.

The appeal of a regionalized system notwithstanding, there are important challenges to implementing such a system. The appropriate metrics designating centers of excellence must be adjudicated, and potential upper volume inflection points at destination centers must be explored to insure that resources, infrastructure, and personnel are scalable. Contingencies for educational and clinical programs supported by consolidated hospitals and for inner city or rural hospitals serving socioeconomically disadvantaged or migrant populations must also be established. Finally, insurance constraints limiting the feasibility of travel across state lines and the hardships of prolonged residence away from home during the fragile interstage period must also be considered.

\section{DEPLOYMENT OF ALTERNATIVE INITIAL}

\section{THERAPY: PRIMARY TRANSPLANTATION AND} HYBRID PALLIATION

Individualized care for HLHS, tailoring strategies to patient characteristics, anatomy, and physiology as advocated by Bacha, ${ }^{36}$ although it may seem orthogonal to the current focus on reducing variation, may be one pathway to improved outcomes. Careful consideration of initial patient factors (including genetic or noncardiac conditions) coupled with institutional or surgeon expertise (ie, matching) should facilitate informed selection. Karamlou and colleagues ${ }^{37}$ documented the early STS-CHSD experience with the hybrid procedure and demonstrated that institutions with high Norwood mortality were appropriately selecting the hybrid procedure as an alternative. Expanding on this thematic approach, leveraging other strategies, such as primary transplantation or hybrid palliation, to a narrow selection of infants who would represent ideal Norwood candidates is another related avenue. It is clear that achieving excellent long-term outcomes requires a significant investment and the ability to integrate empiric best practices realized by others-the decidedly uncomfortable journey of learning.

\section{LONGITUDINAL SURVEILLANCE, TARGETED INTERVENTION, AND UTILITY OF COMPREHENSIVE CARE}

A common element among those centers with comparatively better long-term survival is a focused commitment to iteratively implement changes based on comprehensive analyses of the current longitudinal care paradigm. In a landmark publication, Ghanayem and colleagues ${ }^{38}$ demonstrated the potential benefits of interstage homemonitoring programs, successfully reducing interstage mortality from $\sim 15 \%$ to zero. Learning from this experience, the Joint Council on Congenital Heart Disease
National Pediatric Cardiology Quality Improvement Collaborative subsequently implemented similar practices across 52 contributing institutions. Remarkably, over the course of 4 years, the 53 member institutions collectively reduced interstage mortality across a cohort of more than 1100 Norwood recipients from $9.7 \%$ to $5.3 \% .^{27}$ These national initiatives have now extended to the post-Stage 2 period, with plans to track patient outcomes to the post-Fontan period. Harmonizing avenues of research with other organizations, such as the Cardiac Neurodevelopmental Outcome Collaborative and Pediatric Cardiac Critical Care Consortium, the Joint Council on Congenital Heart Disease National Pediatric Cardiology Quality Improvement Collaborative is committed to understanding metrics that transcend mortality and morbidity, reflecting a comprehensive approach to children with HLHS. These clinical imperatives have been realized by individual institutions committed to adoption of empiric best practices advocated by collaborative or experiential learning. One center, as reported by Karamlou and colleagues, ${ }^{10}$ demonstrated an era-dependent improvement in outcomes by employing technical modifications in the conduct of the Norwood procedure (including preferential adoption of the RVPAS) as a result of the initial SVR data showing early survival advantage for the RVPAS, ${ }^{3}$ the implementation of interstage surveillance programs as elucidated by the initial Milwaukee experience, ${ }^{38}$ development of a dedicated universal cardiothoracic intensive care unit model, and the maturation of a local cardiac transplant program. Pursuit of more accurate and informative diagnostic modalities, specifically magnetic resonance imaging, to identify and quantify early pathologic changes in the systemic ventricle (such as volume loading and hypertrophy), may reduce attrition over time. Magnetic resonance imaging can also be used to provide translational data including flow dynamics that may transform our understanding about the functional health of the single-ventricular circulation. Moreover, close longitudinal surveillance to facilitate early intervention and address correctable anatomic issues, including arch obstruction and systemic atrioventricular valve regurgitation, could salvage a proportion of single-ventricle patients. Pathologic and genetic examination of explanted hearts at the time of transplantation may allow elucidation of the morphologic correlates of failed single-ventricle physiology, especially in those patients in whom the mechanism of failure is unexpected. Other promising initiatives include harnessing new information about the complex genotypic signature of HLHS, increasing the prevalence of prenatal diagnosis, and deployment of fetal intervention to salvage left ventricles capable of supplying adequate systemic output.

Clearly, we have evolved our collective understanding of the management of infants with HLHS, knowledge that has dramatically improved early survival. Excellent long-term 
outcomes remain elusive, the light we cannot yet see. In the end, it may be, therefore, that the deluge of publications emanating from the initial SVR cohort tells an engulfing story in which the ending is still unknown.

\section{Conflict of Interest Statement}

Authors have nothing to disclose with regard to commercial support.

\section{References}

1. William Harvey. Available at: www.quotes.net/authors/40336. Accessed October $22,2018$.

2. Newburger JW, Sleeper LA, Gaynor JW, Hollenbeck-Pringle D, Frommelt PC, Li JS, et al. Transplant-free survival and interventions at 6 years in the SVR trial. Circulation. 2018;137:2246-53.

3. Ohye RG, Sleeper LA, Mahony L, Newburger JW, Pearson GD, Lu M, et al. Comparison of shunt types in the Norwood procedure for single-ventricle lesions, N Engl J Med. 2010;362:1980-92.

4. Jacobs JP, Shahian DM, D'Agostino RS, Mayer JE Jr, Kozower BD, Badhwar V, et al. The Society of Thoracic Surgeons National Database 2018 Annual Report. Ann Thorac Surg. 2018;106:1603-11.

5. Ohye RG, Schonbeck JV, Eghtesady P, Laussen PC, Pizarro C, Shrader P, et al; Pediatric Heart Network Investigators. Cause, timing, and location of death in the Single Ventricle Reconstruction trial. J Thorac Cardiovasc Surg. 2012;144: 907-14.

6. Atz A, Zak V, Mahony L, Uzark K, D'agincourt N, Goldberg DJ, et al. Longitudinal outcomes of patients with single ventricle after the Fontan procedure. J Am Coll Cardiol. 2017;69:2735-44.

7. Wilder TJ, McCrindle BW, Phillips AB, Blackstone EH, Rajeswaran J, Williams WG, et al. Survival and right ventricular performance for matched children after stage-1 Norwood: modified Blalock-Taussig shunt versus right-ventricle-topulmonary-artery conduit. J Thorac Cardiovasc Surg. 2015;150:1440-52.

8. Carillo SA, Mainwaring RD, Schaffer JM, Wright G, Maeda K, Hanley FL, et al. Contemporaneous comparison of the Yasui and the Norwood procedures at a single institution. J Thorac Cardiovasc Surg. 2015;149:508-13.

9. Martin BJ, De Villiers JI, Joffe AR, Bond GY, Acton BV, Ross DB, et al. Hypoplastic left heart syndrome is not associated with worse clinical or neurodevelopmental outcomes than other cardiac pathologies after Norwood-Sano operation. Pediatr Cardiol. 2017;38:922-31.

10. Karamlou T, Zangwill S, Pophal S, Velez D, Nigro JJ. Maximizing survival in hypoplastic left heart syndrome: evolution of a balanced institutional strategy. J Heart Lung Transplant. 2017;36:S264-5.

11. Ohye RG, Gaynor JW, Ghanayem NS, Goldberg CS, Laussen PC, Fommelt PC, et al. Design and rationale of a randomized trial comparing the Blalock-Taussig and right ventricle-pulmonary artery shunts in the Norwood procedure. J Thorac Cardiovasc Surg. 2008;136:968-75.

12. Meza JM, Hickey EJ, Blackstone EH, Jaquiss RDB, Anderson BR, Williams WG, et al. The optimal timing of stage 2 palliation for hypoplastic left heart syndrome: an analysis of the pediatric heart network single ventricle reconstruction trial public data set. Circulation. 2017;136:1737-48.

13. Meza JM, Hickey E, McCrindle B, Blackstone E, Anderson B, Overman D, et al. The optimal timing of stage-2-palliation after the Norwood operation. Ann Thorac Surg. 2018;105:193-9.

14. Alsoufi B, Mahle WT, Manhliot C, Deshpande S, Kogon B, McCrindle BW, et al. Outcomes of heart transplantation in children with hypoplastic left heart syndrome previously palliated with the Norwood procedure. J Thorac Cardiovasc Surg. 2016;151:167-75.

15. Kulkarni A, Neugebauer R, Lo Y, Gao Q, Lamour JM, Weinstein S, et al. Outcomes and risk-factors for listing for heart transplantation after the Norwood procedure: an analysis of the Single Ventricle Reconstruction Trial. J Heart Lung Transplant. 2016;35:306-11.

16. Chinnock RE, Bailey LL. Heart transplantation for congenital heart disease in the first year of life. Curr Cardiol Rev. 2011;7:72-84.

17. Uzark K, Zak V, Shrader P, McCrindle BW, Radojewski E, Varni JW, et al. Assessment of quality of life in young patients with single ventricle after the Fontan operation. J Pediatr. 2016;170:166-72.
18. Gajarski RJ, Towbin JA, Garson A Jr. Fontan palliation versus heart transplantation: a comparison of charges. Am Heart J. 1996;131:1169-74.

19. Fraser CD. Surgical palliation for hypoplastic left heart syndrome: for now, just keep doing what you do best. Circulation. 2018;137:2254-5.

20. Hornik CP, He X, Jacobs JP, Li JS, Jaquiss RD, Jacobs ML, et al. Relative impact of surgeon and center volume on early mortality after the Norwood operation. Ann Thorac Surg. 2012;93:1992-7.

21. Pasquali SK, Ohye RG, Lu M, Kaltman J, Caldarone CA, Pizarro C, et al; Pediatric Heart Network Investigators. Variation in perioperative care across centers for infants undergoing the Norwood procedure. J Thorac Cardiovasc Surg. 2012; 144:915-21.

22. Hill KD, Rhodes JF, Aiyagari R, Baker GH, Bergersen L, Chai PJ, et al. Intervention for recoarctation in the single ventricle reconstruction trial: incidence, risk, and outcomes. Circulation. 2013;128:954-61.

23. Oster ME, Kelleman M, McCracken C, Ohye RG, Mahle WT. Association of digoxin with interstage mortality: results from the Pediatric Heart Network Single Ventricle Reconstruction Trial Public Use Dataset. J Am Heart Assoc. 2016; $5(1)$.

24. Baker-Smith CM, Neish SR, Klitzner TS, Beekman RH III, Kugler JD, Martin GR, et al. Variation in postoperative care following stage 1 palliation for single-ventricle patients: a report from the Joint Council on Congenital Heart Disease National Quality Improvement Collaborative. Congenit Heart Dis. 2011; 2:116-27.

25. Eckhauser A, Pasquali SK, Ravishankar C, Lambert LM, Newburger JW, Atz AM, et al. Variation in care for infants undergoing the Stage II palliation for hypoplastic left heart syndrome. Cardiol Young. 2018;28: 1109-15.

26. Likosky DS. Lessons learned from the Northern New England Cardiovascular Disease Study Group. Prog Pediatr Cardiol. 2012;33:53-6.

27. Anderson JB, Beekman RH III, Kugler JD, Rosenthal GL, Jenkins KJ, Klitzner TS, et al; National Pediatric Cardiology Quality Improvement C. Improvement in interstage survival in a National Pediatric Cardiology Learning Network. Circ Cardiovasc Qual Outcomes. 2015;8:428-36.

28. Pasquali SK. Re-examining interstage home monitoring following the Norwood operation. Circulation. 2015;132:475-8.

29. Devlin P, McCrindle BW, Eghtesady P, Alsoufi B, Blackstone EH, Caldarone CA, et al. Intervention for arch obstruction following Norwood: prevalence, risk factors, and practice variability. J Thorac Cardiovasc Surg. 2019;157:684-95.e8.

30. Gaies M, Pasquali SK, Nicolson SC, Shekerdemian L, et al. Sustainability of infant cardiac surgery early extubation practices after implementation and study. Ann Thorac Surg. 2019;107:1427-33.

31. Welke KF, Pasquali SK, Lin P, Backer CL, Overman DM, Romano JC, et al. Hospital distribution and patient travel patterns for congenital cardiac surgery in the United States. Ann Thorac Surg. 2019;107:574-81.

32. Welke KF, O'Brien SM, Peterson ED, Ungerleider RM, Jacobs ML, Jacobs JP. The complex relationship between surgical case volumes and mortality rates in a national clinical database. J Thorac Cardiovasc Surg. 2009; 137:1133-40.

33. Chang RK, Klitzner TS. Can regionalization decrease the number of deaths for children who undergo cardiac surgery? a theoretical analysis. Pediatrics. 2002; 109:173-81.

34. Lundstrom NR, Bergen H, Bjorkhem G, Jögi P, Sunnegârdh J. Centralization of pediatric heart surgery in Sweden. Pediatr Cardiol. 2000;21:353-7.

35. NHS. Safe and Sustainable: Children's Congenital Cardiac Services. NHS Specialist Services; 2011. Available at: http://www.chfed.org.uk/wp-content/uploads/2012/06/ Safe_and_Sustainable_Review_of_Childrens_Congenital_Cardiac_Services in_England_Pre_Consultation_Business_Case.pdf. Accessed January 15, 2018.

36. Bacha EA. Individualized approach in the management of patients with hypoplastic left heart syndrome. Semin Thorac Cardiovasc Surg Pediatr Card Surg Аnпu. 2013;16:3-6.

37. Karamlou T, Overman D, Hill KD, Wallace A, Pasquali SK, Jacobs JP, et al. Stage 1 hybrid palliation for hypoplastic left heart syndrome-assessment of contemporary patterns of use: an analysis of the Society of Thoracic Surgeons Congenital Heart Surgery Database. J Thorac Cardiovasc Surg. 2015; 149:195-201.

38. Ghanayem NS, Hoffman GM, Mussatto KA, Cava JR, Frommelt PC, Rudd NA, et al. Home surveillance program prevents interstage mortality after the Norwood procedure. J Thorac Cardiovasc Surg. 2003;126:1367-77. 
TABLE E1. Bibliography from the Single Ventricle Reconstruction (SVR) Trial

\begin{tabular}{|c|c|c|c|}
\hline SVR & $\begin{array}{l}\text { Cohen MS, Dagincourt N, Zak V, Baffa JM, Bartz P, Dragulescu A, et al, for the Pediatric Heart Network } \\
\text { Investigators. The impact of the left ventricle on right ventricular function and clinical outcomes in infants } \\
\text { with single-right ventricle anomalies up to } 14 \text { months of age. J Am Soc Echocardiogr. 2018;31:1151-7. }\end{array}$ & 2018 & Main \\
\hline SVR II & $\begin{array}{l}\text { Mahle WT, Hu C, Trachtenberg F, Menteer J, Kindel SJ, Dipchand AI, et al; Pediatric Heart Network } \\
\text { Investigators. Heart failure after the Norwood procedure: an analysis of the Single Ventricle Reconstruction } \\
\text { Trial. J Heart Lung Transplant. 2018;37:879-85. }\end{array}$ & 2018 & Main \\
\hline SVR & $\begin{array}{l}\text { Jean-St-Michel E, Meza JM, Maguire J, Coles J, McCrindle BW. Survival to stage II with ventricular } \\
\text { dysfunction: secondary analysis of the Single Ventricle Reconstruction Trial. Pediatr Cardiol. 2018;39:955- } \\
66 .\end{array}$ & 2018 & Public data \\
\hline SVR II & $\begin{array}{l}\text { Newburger JW, Sleeper LA, Gaynor JW, Hollenbeck-Pringle D, Frommelt PC, Li JS, et al; Pediatric Heart } \\
\text { Network Investigators. Transplant-free survival and interventions at } 6 \text { years in the Single Ventricle } \\
\text { Reconstruction Trial. Circulation. 2018;137:2246-53. }\end{array}$ & 2018 & Main \\
\hline SVR & $\begin{array}{l}\text { Gupta P, Chakraborty A, Gossett JM, Rettiganti M. A prognostic tool to predict outcomes in children } \\
\text { undergoing the Norwood operation. J Thorac Cardiovasc Surg. 2017;154:2030-7. }\end{array}$ & 2017 & Public data \\
\hline SVR & $\begin{array}{l}\text { Karamlou T, Velez DA, Nigro JJ. Encrypted prediction: a hacker's perspective. J Thorac Cardiovasc Surg. } \\
\text { 2017;154:2038-40. }\end{array}$ & 2017 & Public data \\
\hline SVR & $\begin{array}{l}\text { Meza JM, Hickey EJ, Blackstone EH, Jaquiss RDB, Anderson BR, Williams WG, et al. The optimal timing of } \\
\text { stage } 2 \text { palliation for hypoplastic left heart syndrome: an analysis of the Pediatric Heart Network Single } \\
\text { Ventricle Reconstruction Trial Public Data Set. Circulation. 2017;136:1737-48. }\end{array}$ & 2017 & Public data \\
\hline SVR-ISV & $\begin{array}{l}\text { Ramroop R, Manase G, Lu D, Manase D, Chen S, Kim R, et al. Adrenergic receptor genotypes influence } \\
\text { postoperative outcomes in infants in the Single-Ventricle Reconstruction Trial. J Thorac Cardiovasc Surg. } \\
\text { 2017;154:1703-10.e3. }\end{array}$ & 2017 & Ancillary \\
\hline SVR & $\begin{array}{l}\text { McHugh KE, Pasquali SK, Hall MA, Scheurer MA. Cost variation across centers for the Norwood operation. } \\
\text { Ann Thorac Surg. 2018;105:851-6. }\end{array}$ & 2017 & Public data \\
\hline SVR II & $\begin{array}{l}\text { Mussatto KA, Hollenbeck-Pringle D, Trachtenberg F, Sood E, Sananes R, Pike NA, et al, for the Pediatric } \\
\text { Heart Network Investigators. Utilization of early intervention services in young children with hypoplastic } \\
\text { left heart syndrome. Cardiol Young. 2018;28:126-33. }\end{array}$ & 2017 & Main \\
\hline SVR & $\begin{array}{l}\text { Mathur K, Lamour J, Hsu D, Aydin S. Safety of enalapril in infants: data from the Pediatric Heart Network } \\
\text { Infant with Single Ventricle Trial. J Am Coll Cardiol. 2017;69(11 suppl) }\end{array}$ & 2017 & Public data \\
\hline SVR & $\begin{array}{l}\text { Jean-St-Michel E, Meza JM, Coles J, Maguire J, McCrindle BW. Risk factors for death or heart transplant for } \\
\text { patients with right ventricular dysfunction after the Norwood procedure; a secondary analysis of the Single } \\
\text { Ventricle Reconstruction Trial. J Heart Lung Transplant. 2017;36(suppl):S161-2. }\end{array}$ & 2017 & Public data \\
\hline SVR II & $\begin{array}{l}\text { Burch PT, Ravishankar C, Newburger JW, Lambert LM, Pemberton VL, Granger S, et al, on behalf of the } \\
\text { Pediatric Heart Network Investigators. Assessment of growth six years after the Norwood procedure: results } \\
\text { from the Single Ventricle Reconstruction Trial. J Pediatr. 2017;180:270-4.e6. }\end{array}$ & 2017 & Main \\
\hline SVR & $\begin{array}{l}\text { Oster ME, Chen S, Dagincourt N, Bar-Cohen Y, Brothers M, Cain N, for the Pediatric Heart Network } \\
\text { Investigators. Development and impact of arrhythmias after the Norwood procedure: a report from the } \\
\text { Pediatric Heart Network. J Thorac Cardiovasc Surg. 2017;153:638-45.e2. }\end{array}$ & 2017 & Main \\
\hline SVR & $\begin{array}{l}\text { McHugh KE, Pasquali SK, Hall MA, Scheurer MA. Impact of postoperative complications on hospital costs } \\
\text { following the Norwood operation. Cardiol Young. 2016;26:1303-9. }\end{array}$ & 2016 & Scholar \\
\hline SVR & $\begin{array}{l}\text { Bradley SM. The Single Ventricle Reconstruction Trial: the data goes public. J Thorac Cardiovasc Surg. } \\
\text { 2016;152:195-6. }\end{array}$ & 2016 & Public Data \\
\hline SVR & $\begin{array}{l}\text { Oster ME, Kelleman M, McCracken C, Ohye RG, Mahle WT. Association of digoxin with interstage mortality: } \\
\text { results from the Pediatric Heart Network Single Ventricle Reconstruction Trial Public Use Dataset. J Am } \\
\text { Heart Assoc. 2016;5:e02566. }\end{array}$ & 2016 & Public data \\
\hline SVR & $\begin{array}{l}\text { Elhoff JJ, Chowdhury SM, Zyblewski SC, Atz AM, Bradley SM, Graham EM. Intraoperative steroid use and } \\
\text { outcomes following the Norwood procedure: an analysis of the Pediatric Heart Network's Public Database. } \\
\text { Pediatr Crit Care Med. 2016;17:30-5. }\end{array}$ & 2016 & Public Data \\
\hline SVR & $\begin{array}{l}\text { Meza JM, Hickey EJ, Blackstone EH, Jaquiss RDB, Anderson BR, Williams WG, et al. The optimal timing of } \\
\text { stage } 2 \text { palliation for hypoplastic left heart syndrome: an analysis of the Pediatric Heart Network Single } \\
\text { Ventricle Reconstruction Trial public data set. Circulation. 2017;136:1737-48. }\end{array}$ & 2016 & Public data \\
\hline SVR & $\begin{array}{l}\text { Mah DY, Cheng H, Alexander ME, Sleeper L, Newburger JW, Del Nido PJ, et al. Heart block following stage } 1 \\
\text { palliation of hypoplastic left heart syndrome. J Thorac Cardiovasc Surg. 2016;152:189-94. }\end{array}$ & 2016 & Public data \\
\hline
\end{tabular}


TABLE E1. Continued

\begin{tabular}{|c|c|c|c|}
\hline SVR & $\begin{array}{l}\text { Andersen ND, Meza JM, Byler MR, Lodge AJ, Hill KD, Hornik CP, et al. Comparison of right ventricle- } \\
\text { pulmonary artery shunt position in the Single Ventricle Reconstruction trial. J Thorac Cardiovasc Surg. } \\
\text { 2017;153:1490-500.e1. }\end{array}$ & 2016 & Public data \\
\hline SVR & $\begin{array}{l}\text { Kulkarni A, Neugebauer R, Lamour JM, Hsu DT. Predictors for listing for transplant in infants with } \\
\text { hypoplastic left heart syndrome: an analysis of the Single Ventricle Reconstruction Trial. J Heart Lung } \\
\text { Transplant. 2016;35:306-11. }\end{array}$ & 2016 & Public data \\
\hline SVR II & $\begin{array}{l}\text { Ravishankar C, Gerstenberger E, Atz AM, Affolter J, Bradley T, Menon S, et al, for the Pediatric Heart } \\
\text { Network. Factors affecting Fontan length of stay: results from the single ventricle reconstruction trial. } J \\
\text { Thorac Cardiovasc Surg. 2016;151:669-75.e1 }\end{array}$ & 2016 & Main \\
\hline SVR & $\begin{array}{l}\text { Kane AM, Kelleman MS, Oster ME. Predictors of ECMO Survival Following the Norwood Procedure: An } \\
\text { Analysis of the Pediatric Heart Network Public Use Dataset. Read at the American Academy of Pediatrics, } \\
\text { Washington, DC, October 24-27, } 2015 .\end{array}$ & 2015 & Public data \\
\hline SVR & $\begin{array}{l}\text { Johnson JT, Sleeper LA, Chen S, Ohye RG, Gaies MG, Williams IA, et al. Associations between day of } \\
\text { admission and day of surgery on outcome and resource utilization in infants with hypoplastic left heart } \\
\text { syndrome undergoing stage I palliation from the Single Ventricle Reconstruction Trial. Am J Cardiol. } \\
\text { 2015;116:1263-9. }\end{array}$ & 2015 & Main \\
\hline SVR & $\begin{array}{l}\text { Hill GD, Frommelt PC, Stelter J, Campbell MJ, Cohen MS, Kharouf R, et al. Impact of initial Norwood shunt } \\
\text { type on right ventricular deformation: the Single Ventricle Reconstruction Trial (ancillary). J Am Soc } \\
\text { Echocardiogr. 2015;28:517-21. }\end{array}$ & 2015 & Main \\
\hline SVR & $\begin{array}{l}\text { Oster ME, Chen S, Gerstenberger E, Bar-Cohen Y, Brothers M, Cain N, et al, for the Pediatric Heart Network } \\
\text { Investigators. Risk factors for the development of tachyarrhythmia following the Norwood procedure in the } \\
\text { Single Ventricle Reconstruction Trial. J Am Coll Cardiol. 2015;65:A494. }\end{array}$ & 2015 & Main \\
\hline SVR & $\begin{array}{l}\text { Kulkarni A, Neugebauer R, Lamour JM, Hsu DT. Predictors for listing for transplant in infants with } \\
\text { hypoplastic left heart syndrome: an analysis of the Single Ventricle Reconstruction Trial. Circulation. } \\
\text { 2014;130:A17246. }\end{array}$ & 2014 & Public data \\
\hline SVR & $\begin{array}{l}\text { Nathan M, Sleeper LA, Ohye RG, Frommelt PC, et al. Technical performance score is associated with } \\
\text { outcomes after the Norwood procedure. J Thorac Cardiovasc Surg. 2014;148:2208-13. }\end{array}$ & 2014 & Main \\
\hline SVR & $\begin{array}{l}\text { Nathan M, Sleeper LA, Ohye RG, Frommelt PC, Gaynor JW, Pizarro C, et al. Technical performance score is } \\
\text { associated with outcomes after the Norwood procedure. J Thorac Cardiovasc Surg. 2014;148:2208-13. }\end{array}$ & 2014 & Main \\
\hline SVR & $\begin{array}{l}\text { Lambert LM, Pike NA, Medoff-Cooper B, Zak V, Pemberton LV, Young-Borkowski L, et al, for the Pediatric } \\
\text { Heart Network Investigators. Variation in feeding practices following the Norwood procedure. J Pediatrics } \\
\text { 2014;164:237-42.e1. }\end{array}$ & 2014 & Main \\
\hline SVR & $\begin{array}{l}\text { Schwartz SM, Lu M, Ohye RG, Hill KD, Atz AM, Naim M, et al, for the Pediatric Heart Network Investigators. } \\
\text { Risk factors for prolonged length of stay after the stage } 2 \text { procedure in the single-ventricle reconstruction } \\
\text { trial. J Thorac Cardiovasc Surg. 2014;147:1791-8. }\end{array}$ & 2014 & Main \\
\hline SVR II & $\begin{array}{l}\text { Frommelt PC, Gerstenberger E, Cnota JF, Cohen MS, Gorentz J, Hill K, et al, for the Pediatric Heart Network } \\
\text { Investigators. Impact of initial shunt type on cardiac size and function in children with single right ventricle } \\
\text { anomalies before the Fontan procedure: the Single Ventricle Reconstruction Extension Trial. J Am Coll } \\
\text { Cardiol. 2014;64:2026-35. }\end{array}$ & 2014 & Main \\
\hline SVR II & $\begin{array}{l}\text { Burch P, Anderson J, Sleeper LA, Newburger JW, Williams I, Gerstenberger E, et al. Longitudinal assessment } \\
\text { of growth in hypoplastic left heart syndrome: results from the single ventricle reconstruction trial. J Am } \\
\text { Heart Assoc. 2014;3:e00079. }\end{array}$ & 2014 & Main \\
\hline SVR II & $\begin{array}{l}\text { Goldberg CS, Lu M, Sleeper LA, Mahle WT, Gaynor JW, Williams I, et al. Factors associated with } \\
\text { neurodevelopment for children with single ventricle lesions. J. Pediatr. 2014;165:490-6. }\end{array}$ & 2014 & Main \\
\hline SVR II & $\begin{array}{l}\text { Newburger JW, Sleeper L, Pearson G, Mahle W, Dunbar-Masterson C, Mital S, et al, for the Pediatric Heart } \\
\text { Network. Transplantation-free survival and interventions at } 3 \text { years in the single ventricle reconstruction } \\
\text { trial. Circulation. 2014;129:2013-20. }\end{array}$ & 2014 & Main \\
\hline SVR & $\begin{array}{l}\text { Oster ME, Chen S, Pober D, Bar-Cohen Y, Brothers M, Cain N, et al, for the Pediatric Heart Network } \\
\text { Investigators. Risk Factors for the Development of Tachyarrhythmia Following the Norwood Procedure in } \\
\text { the Single Ventricle Reconstruction Trial. Circulation. 2014;130:A13312. }\end{array}$ & 2014 & Main \\
\hline
\end{tabular}


TABLE E1. Continued

\begin{tabular}{|c|c|c|c|}
\hline SVR & $\begin{array}{l}\text { Plummer ST, Hornik CP, Baker H, Fleming GA, Foerster S, Ferguson E, et al. Maladaptive aortic properties } \\
\text { after the Norwood procedure: an angiographic analysis of the Pediatric Heart Network Single Ventricle } \\
\text { Reconstruction Trial. American Heart Association Scientific Sessions. Circulation. 2014;130:A18067 }\end{array}$ & 2014 & Main \\
\hline SVR & $\begin{array}{l}\text { Johnson J, Sleeper L, Chen S, Williams I, Sachdeva R, Pruetz J, et al, for the Pediatric Heart Network } \\
\text { Investigators. Does day of the week of admission affect outcome and resource utilization in infants } \\
\text { undergoing stage I palliation? A report from the single ventricle reconstruction trial. Congenit Heart Dis. } \\
\text { 2014;9:454. }\end{array}$ & 2014 & Main \\
\hline SVR & $\begin{array}{l}\text { Hill G, Frommelt P, Stelter J, Saudek D. Right ventricular deformation at } 14 \text { months is not impacted by initial } \\
\text { Norwood shunt type: the Single Ventricle Reconstruction Trial. J Am Coll Cardiol. 2014;63(12 suppl } \\
\text { A):A152. }\end{array}$ & 2014 & Main \\
\hline SVR II & $\begin{array}{l}\text { Ravishankar C, Gerstenberger E, Atz AM, Affolter J, Bradley T, Menon S, et al, for the Pediatric Heart } \\
\text { Network. Factors affecting Fontan length of stay: results from the Single Ventricle Reconstruction Trial. } \\
\text { Circulation. 2014;130:A12621. }\end{array}$ & 2014 & Main \\
\hline SVR & $\begin{array}{l}\text { Hill K, Rhodes JF, Aiyagari R, Baker GH, Bergersen L, Chai PJ, et al. Intervention for re-coarctation in the } \\
\text { Single Ventricle Reconstruction Trial: incidence, risk and outcomes. Circulation. 2013;128:954-61. }\end{array}$ & 2013 & Main \\
\hline SVR & $\begin{array}{l}\text { Aiyagari R, Rhodes JF, Shrader P, Radtke WA, Bandisode R, Bergersen L, et al, for the Pediatric Heart } \\
\text { Network Investigators. Impact of pre-stage II hemodynamics and pulmonary artery anatomy on 12-month } \\
\text { outcome in the Single Ventricle Reconstruction Trial. J Thorac Cardiovasc Surg. 2013;148:1467-74. }\end{array}$ & 2013 & Main \\
\hline SVR & $\begin{array}{l}\text { Marx GR, Shirali G, Levine JC, Guey LT, Cnota JF, Baffa JM, et al, for the Pediatric Heart Network } \\
\text { Investigators. Multi-center study comparing shunt type in the Norwood procedure for single-ventricle } \\
\text { lesions: 3-dimensional echocardiographic analysis. Circ Cardiovasc Imaging. 2013;6:934-42. }\end{array}$ & 2013 & Main \\
\hline SVR & $\begin{array}{l}\text { Hill K, Rhodes JF, Aiyagari R, Baker GH, Bergersen L, Chai PJ, et al. Intervention for re-coarctation in the } \\
\text { Single Ventricle Reconstruction Trial: incidence, risk and outcomes. Circulation. 2013;128:954-61. }\end{array}$ & 2013 & Main \\
\hline SVR & $\begin{array}{l}\text { Frommelt PC, Baffa J, Border WL, Bradley TJ, Colan S, Gerstenberger E, et al, for the Pediatric Heart } \\
\text { Network Investigators. Doppler flow patterns in the right ventricle-to-pulmonary artery shunt and neo-aorta } \\
\text { in infants with single right ventricle anomalies: Impact on outcome after initial staged palliations. J Am Soc } \\
\text { Echocardiogr. 2013;26:521-9. }\end{array}$ & 2013 & Main \\
\hline SVR & $\begin{array}{l}\text { Mahle WT, Lu M, Ohye RG, Gaynor JW, Goldberg CS, Sleeper LA, et al, for the Pediatric Heart Network } \\
\text { Investigators. A predictive model for neurodevelopmental outcome after the Norwood procedure. Pediatr } \\
\text { Cardiol. 2013;34:327-33. }\end{array}$ & 2013 & Main \\
\hline SVR & $\begin{array}{l}\text { Hill K, Rhodes JF, Aiyagari R, Baker GH, Bergersen L, Chai PJ, et al. Intervention for residual or recurrent } \\
\text { coarctation in the Single Ventricle Reconstruction Trial: Incidence, risk and outcomes. Cardiovasc J Africa. } \\
\text { 2013;24:225. }\end{array}$ & 2013 & Main \\
\hline SVR & $\begin{array}{l}\text { Frommelt PC, Baffa J, Border WL, Bradley TJ, Colan S, Gerstenberger E, et al, for the Pediatric Heart } \\
\text { Network Investigators. Doppler flow patterns in the right ventricle-to-pulmonary artery shunt and neo-aorta } \\
\text { in infants with single right ventricle anomalies-impact on outcome after initial staged palliations. J Am Coll } \\
\text { Cardiol. 2013;61:E440. }\end{array}$ & 2013 & Main \\
\hline SVR II & $\begin{array}{l}\text { Burch P, Anderson J, Sleeper LA, Newburger JW, Williams I, Gerstenberger E, et al. Factors affecting growth } \\
\text { from birth to Norwood discharge: results from the Single Ventricle Reconstruction Trial. Cardiovasc J } \\
\text { Africa. 2013;24:148. }\end{array}$ & 2013 & Main \\
\hline SVR II & $\begin{array}{l}\text { Frommelt PC, Cnota JF, Cohen MS, Gerstenberger E, Gorentz J, Hill K, et al, for the Pediatric Heart Network } \\
\text { Investigators. Changes in cardiac size and function in children with Single Right Ventricle anomalies after } \\
\text { Norwood-RV remodeling after the first year varies by initial shunt type. J Am Coll Cardiol. 2013;61:E557. }\end{array}$ & 2013 & Main \\
\hline SVR & $\begin{array}{l}\text { Gaynor, JW. Neonatal cardiac surgery: HLHS in favor of Stage I/BT Shunt. AATS Postgraduate Talk, April 29, } \\
2012 .\end{array}$ & 2012 & Main \\
\hline SVR & $\begin{array}{l}\text { Ohye RG, Schonbeck JV, Eghtesady P, Laussen PC, Pizarro C, Shrader P, et al, for the Pediatric Heart Network } \\
\text { Investigators. Cause, timing and location of death in the Single Ventricle Reconstruction Trial. J Thorac } \\
\text { Cardiovasc Surg. 2012;144:907-14. }\end{array}$ & 2012 & Main \\
\hline SVR & $\begin{array}{l}\text { Ghanayem NS, Allen KR, Tabbutt S, Atz AM, Clabby ML, Cooper DS, et al; Pediatric Heart Network } \\
\text { Investigators. Interstage mortality after the Norwood procedure: results of the multicenter Single Ventricle } \\
\text { Reconstruction trial. J Thorac Cardiovasc Surg. 2012;144:896-906. }\end{array}$ & 2012 & Main \\
\hline
\end{tabular}


TABLE E1. Continued

\begin{tabular}{|c|c|c|c|}
\hline SVR & $\begin{array}{l}\text { Tabbutt S, Ghanayem N, Cooper DS, Frank DU, Lu M, Frommelt P, et al, for the Pediatric Heart Network } \\
\text { Investigators. Risk factors for hospital morbidity and mortality after the Norwood procedure: a report from } \\
\text { the Pediatric Heart Network Single Ventricle Reconstruction Trial. J Thorac Cardiovasc Surg. } \\
\text { 2012;144:882-95. }\end{array}$ & 2012 & Main \\
\hline SVR & $\begin{array}{l}\text { Pasquali SK, Ohye RG, Lu M, Kaltman J, Caldarone C, Pizarro C, et al, for the Pediatric Heart Network } \\
\text { Investigators. Variation in perioperative care across centers for infants undergoing the Norwood procedure. } \\
\text { J Thorac Cardiovasc Surg. 2012;144:915-21. }\end{array}$ & 2012 & Main \\
\hline SVR & $\begin{array}{l}\text { Frommelt P, Guey LT, Bradley T, Colan SD, Ensing G, Gorentz J, et al, for the Pediatric Heart Network } \\
\text { Investigators. Does initial shunt type for the Norwood procedure affect echocardiographic measures of } \\
\text { cardiac size and function during infancy? The Single Ventricle Reconstruction Trial. Circulation. } \\
\text { 2012;125:2630-8. }\end{array}$ & 2012 & Main \\
\hline SVR & $\begin{array}{l}\text { Newburger JW, Sleeper LA, Bellinger DC, Goldberg CS, Tabbutt S, Lu M, et al, for the Pediatric Heart } \\
\text { Network Investigators. Early developmental outcome in children with hypoplastic left heart syndrome and } \\
\text { related anomalies: the Single Ventricle Reconstruction Trial. Circulation. 2012;125:2081-91. }\end{array}$ & 2012 & Main \\
\hline SVR & $\begin{array}{l}\text { Tweddell J, Sleeper LA, McCrindle BW, Williams IA, Mahony L, Pizarro C, et al, for the Pediatric Heart } \\
\text { Network Investigators. Intermediate-term mortality and cardiac transplantation in infants with single- } \\
\text { ventricle lesions: risk factors and their interaction with shunt type. J Thorac Cardiovasc Surg. } \\
\text { 2012;144:152-159.e2. }\end{array}$ & 2012 & Main \\
\hline SVR & $\begin{array}{l}\text { Hill K, Rhodes JF, Aiyagari R, Baker GH, Bergersen L, Chai PJ, et al. Intervention for residual or recurrent } \\
\text { coarctation in the Single Ventricle Reconstruction Trial: incidence, risk and outcomes. Circulation. } \\
\text { 2012;126:A9363. }\end{array}$ & 2012 & Main \\
\hline SVR & $\begin{array}{l}\text { Schwartz SM, Lu M, Ohye RG, Hill KD, Atz AM, Naim M, et al, for the Pediatric Heart Network Investigators. } \\
\text { Risk factors for prolonged length of stay following stage II procedure in the Single Ventricle Reconstruction } \\
\text { Trial. Circulation. 2012;126:A16568. }\end{array}$ & 2012 & Main \\
\hline SVR & $\begin{array}{l}\text { Lambert LM, Pike NA, Medoff-Cooper B, Zak V, Pemberton LV, Young-Borkowski L, et al, for the Pediatric } \\
\text { Heart Network Investigators. Feeding practice variation at hospital discharge following the Norwood } \\
\text { procedure: a report from the Pediatric Heart Network Single Ventricle Reconstruction trial. J Am Coll } \\
\text { Cardiol. 2012;59:A182. }\end{array}$ & 2012 & Main \\
\hline SVR II & $\begin{array}{l}\text { Goldberg CS, Lu M, Mahle WT, Gaynor JW, Williams I, Mussatto KA, et al, for the Pediatric Heart Network } \\
\text { Investigators. Factors associated with impaired neurodevelopment at } 3 \text { years of age in children with single } \\
\text { right ventricle lesions. Circulation. 2012;126:A13230. }\end{array}$ & 2012 & Main \\
\hline SVR II & $\begin{array}{l}\text { Newburger JW, Sleeper L, Pearson G, Mahle W, Dunbar-Masterson C, Mital S, et al, for the Pediatric Heart } \\
\text { Network. Transplant-free survival, catheter interventions, and events at } 3 \text { years in the Single Ventricle } \\
\text { Reconstruction trial. Circulation. 2012;126:A11328. }\end{array}$ & 2012 & Main \\
\hline SVR & $\begin{array}{l}\text { Virzi L, Pemberton V, Ohye RG, Tabbutt S, Lu M, Atz TC, et al. Reporting adverse events in a surgical trial for } \\
\text { complex congenital heart disease: the Pediatric Heart Network experience. J Thoracic Cardiovasc Surg. } \\
\text { 2011;142:531-7. }\end{array}$ & 2011 & Main \\
\hline SVR & $\begin{array}{l}\text { Johnson JN, Ansong AK, Li JS, Xu M, Gorentz J, Hehir DH, et al. Celiac artery flow pattern in infants with } \\
\text { single right ventricle following the Norwood procedure with a modified Blalock-Taussig or right ventricle to } \\
\text { pulmonary artery shunt. Pediatr Cardiol. 2011;32:479-86. }\end{array}$ & 2011 & Main \\
\hline SVR & $\begin{array}{l}\text { Goldberg CS, Allen K, Tabbutt S, Atz AM, Bhat M, Clabby M, et al, for the Pediatric Heart Network } \\
\text { Investigators. Interstage mortality after the Norwood procedure: results of the multi-center Single Ventricle } \\
\text { Reconstruction trial. Circulation. 2011;124:A12185. }\end{array}$ & 2011 & Main \\
\hline SVR & $\begin{array}{l}\text { Frommelt P, Guey LT, Bradley T, Colan SD, Ensing G, Gorentz J, et al, on behalf of the Pediatric Heart } \\
\text { Network Investigators. Does Initial Shunt Type for the Norwood Procedure impact echocardiographic } \\
\text { measures of cardiac size and function during infancy? The Single Ventricle Reconstruction Trial. } \\
\text { Circulation. 2011;124:A13454. }\end{array}$ & 2011 & Main \\
\hline SVR & $\begin{array}{l}\text { Tweddell J, Sleeper LA, McCrindle BW, Williams IA, Mahony L, Pizarro C, et al, for the Pediatric Heart } \\
\text { Network Investigators. Risk factors for mortality in the Single Ventricle Reconstruction Trial: beyond shunt } \\
\text { type. Circulation. 2011;124:A11634. }\end{array}$ & 2011 & Main \\
\hline SVR & $\begin{array}{l}\text { Newburger JW, Sleeper LA, Bellinger DC, Goldberg CS, Tabbutt S, Lu M, et al, for the Pediatric Heart } \\
\text { Network Investigators. Early neurodevelopmental outcome in hypoplastic left heart syndrome and related } \\
\text { anomalies: the Single Ventricle Reconstruction trial. Circulation. 2011;124:A8457. }\end{array}$ & 2011 & Main \\
\hline
\end{tabular}


TABLE E1. Continued

\begin{tabular}{|c|c|c|c|}
\hline SVR & $\begin{array}{l}\text { Tabbutt S, Ghanayem N, Cooper DS, Frank DU, Lu Minmin, Frommelt P, et al, for the Pediatric Heart Network } \\
\text { Investigators. Risk factors for hospital mortality and morbidity following the Norwood Procedure: results } \\
\text { from the multicenter Single Ventricle Reconstruction trial. Circulation. 2011;124:A8160. }\end{array}$ & 2011 & Main \\
\hline SVR & $\begin{array}{l}\text { Ravishankar C, Tabbutt S, Allen K, Cooper DS, Frank DU, Frommelt P, et al, for the Pediatric Heart Network } \\
\text { Investigators. Impact of extracorporeal membrane oxygenation and cardiopulmonary resuscitation on } \\
\text { Norwood procedure outcomes: data from the Single Ventricle Reconstruction trial. Circulation. } \\
\text { 2011;124:A9897. }\end{array}$ & 2011 & Main \\
\hline SVR & $\begin{array}{l}\text { Ohye RG, Schonbeck JV, Eghtesady P, Laussen PC, Pizarro C, Shrader P, et al, for the Pediatric Heart Network } \\
\text { Investigators. Cause, timing and location of death in the Single Ventricle Reconstruction Trial. Circulation. } \\
\text { 2011;124:A10098. }\end{array}$ & 2011 & Main \\
\hline SVR & $\begin{array}{l}\text { Ohye RG, Pearson GD, Lu M, Kaltman J, Caldarone C, Derby C, et al, for the Pediatric Heart Network } \\
\text { Investigators. Variation in perioperative management of Norwood surgery in the Pediatric Heart Network } \\
\text { Single Ventricle Reconstruction trial. J Am Coll Cardiol. 2011:57:E428. }\end{array}$ & 2011 & Main \\
\hline SVR & $\begin{array}{l}\text { Ohye R. The Pediatric Heart Network Single Ventricle Reconstruction Trial. A New Standard for the use of } \\
\text { evidence-based medicine in congenital heart surgery. 53rd Annual Meeting of Kansai Association for } \\
\text { Thoracic Surgery, Nagoya, Japan, June 25, 2010. }\end{array}$ & 2010 & Main \\
\hline SVR & $\begin{array}{l}\text { Ohye, R. Results of a randomized trial of BT shunt vs RV-PA conduit in neonates undergoing the Norwood } \\
\text { Procedure. Presented at the CHOP 13th Annual Update on Pediatric Cardiovascular Disease, Orlando, } \\
\text { Florida, February } 2010 .\end{array}$ & 2010 & Main \\
\hline SVR & $\begin{array}{l}\text { Atz AM, Travison TG, Williams IA, Pearson GD, Mahle WT, Sklansky MS, et al. Prenatal diagnosis and risk } \\
\text { factors for preoperative death in neonates with single right ventricle and systemic outflow obstruction: } \\
\text { screening data from the Pediatric Heart Network Single Ventricle Reconstruction Trial. J Thorac } \\
\text { Cardiovasc Surg. 2010;140:1245-50. }\end{array}$ & 2010 & Main \\
\hline SVR & $\begin{array}{l}\text { Ohye RG, Sleeper LA, Mahony L, Newburger JW, Pearson GD, Lu M, et al. Comparison of shunt types in the } \\
\text { Norwood procedure for single-ventricle lesions. N Engl J Med. 2010;362:1980-92. }\end{array}$ & 2010 & Main \\
\hline SVR & $\begin{array}{l}\text { Mussatto K, Young-Borkowski L, Leske J, Ghanayem N, Sawin K, the Family Adaptation Study Group. } \\
\text { Family stress, coping, and outcomes following the diagnosis of Single Ventricle Congenital Heart Disease } \\
\text { (SVCHD) in a newborn. Presented as a poster at the World Congress, Australia, 2009. }\end{array}$ & 2009 & Main \\
\hline SVR & $\begin{array}{l}\text { Ohye RG, Tabbutt S, Sleeper LA, Pearson GD, Newburger JW, Mahony L, et al. Outcomes of the Norwood } \\
\text { operation in infants randomized to a modified Blalock-Taussig versus right ventricle-to-pulmonary artery } \\
\text { shunt: the Pediatric Heart Network Single Ventricle Reconstruction Trial. Circulation Suppl. } \\
\text { 2009;120:S560. }\end{array}$ & 2009 & Main \\
\hline SVR & $\begin{array}{l}\text { Atz AM, Travison TG, Williams IA, Pearson GD, Mahle WT, Sklansky MS, et al. Impact of prenatal diagnosis } \\
\text { and risk factors for preoperative death in neonates with Single Right Ventricle: screening results from the } \\
\text { Pediatric Heart Network Single Ventricle Reconstruction trial. J Am Coll Cardiol. 2009;53(suppl A):360A- } \\
\text { 1A. }\end{array}$ & 2009 & Main \\
\hline SVR & $\begin{array}{l}\text { Ohye RG, Gaynor JW, Ghanayem NS, Goldberg CS, Laussen PC, Frommelt PC, et al, for the Pediatric Heart } \\
\text { Network Investigators. Design and rationale of a randomized trial comparing the Blalock-Taussig and right } \\
\text { ventricle-pulmonary artery shunts in the Norwood procedure. J Thorac Cardiovasc Surg. 2008;136:968-75. }\end{array}$ & 2008 & Main \\
\hline SVR & $\begin{array}{l}\text { Ohye RG, Devaney EJ, Hirsch JC, Bove EL. The modified Blalock-Taussig shunt versus the right ventricle-to- } \\
\text { pulmonary artery conduit for the Norwood procedure. Pediatr Cardiol. 2007;28:122-5. }\end{array}$ & 2007 & Main \\
\hline
\end{tabular}

